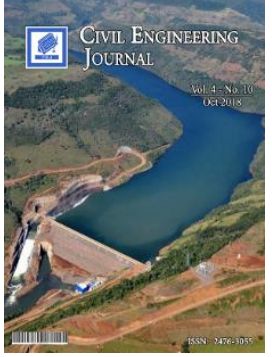

\title{
Effect of Rice Husk Ash and Water-Cement Ratio on Strength of Concrete
}

\author{
Naraindas Bheel a, Shanker Lal Meghwar ${ }^{\text {a*, }}$, Sohail Ahmed Abbasi ${ }^{\text {b }}$, Lal Chand Marwari a, \\ Jabbar Ahmed Mugeri ${ }^{\mathrm{b}}$, Rameez Ali Abbasi ${ }^{\mathrm{b}}$ \\ ${ }^{a}$ Department of Civil Engineering, Mehran University of Engineering \& Technology, Jamshoro 76062, Pakistan. \\ ${ }^{b}$ Department of Civil Engineering, Quaid-E-Awam University College of Engineering Science \& Technology, Larkana 77150, Pakistan.
}

Received 07 August 2018; Accepted 07 October 2018

\begin{abstract}
In present status quo, number of researcher are working on waste materials as potential supplement for any of the constituent of concrete to cope with sustainable development. As, the ingredients which constitute the body and give strength to concrete are natural available limited material and has to deplete one day. Thus, there is desperately need of alternate that may replace the limited natural resources. In this regard, this study focuses the rice husk ash (waste stuff) as partial replacement of cement and its possible impact on strength of concrete. In addition, this research work also this research work is conducted to investigate the effect of water-cement ratio on the strength of concrete at $10 \%$ partially replacement of Rice husk ash (RHA) by the weight of cement. RHA is a mineral admixture obtained by burning husk at certain temperature. Since as per pervious researches, the physical and chemical properties of RHA are very reactive Pozzolans and possess binding properties so can be used as cement supplement. Therefore, for laboratory experimental work, total 144 cubical and 72 cylindrical. In this research, number of concrete specimens were cast and tested at 1:2:4 mix ratio with various w/c ratios i.e. $0.45,0.50$ and 0.60 . Further, at each specified water-cement ratio, two mechanical properties (compressive and splitting tensile strength) were determined in Universal Testing Machine (UTM). These physical properties of concrete were investigated at 7, 14, 28 and 56 days curing period. The experimental results show that the compressive strength gets increased up to $14.51 \%$ and tensile splitting test strength increased up to $10.71 \%$ at the $\mathrm{w} / \mathrm{c}$ ratio of 0.45 . The workability of plain fresh concrete at all $\mathrm{w} / \mathrm{c}$ ratios is slightly greater than the workability of concrete blended with 10\% RHA. Thus, RHA improves the properties of concrete when used in specific amount. As a result, it can reduce the overall cost of construction and it will reduce the adverse environmental effect.
\end{abstract}

Keywords: RHA; W/C Ratio; Strength of Concrete; Environmental Pollution.

\section{Introduction}

Conventional materials of construction like cement, sand and granite are highly pre-requisites in construction industry, of which concrete is the basic and widely used cementitious material in civil engineered structures. Since concrete is far more in need and is amply consumed industrially material world-wide, its versatile nature, inevitable dependence and economic feasibility to quench the requirements has placed it as the top most building material [1-3]. With the development around the globe, the use, production and the environmental hazardous in making of cement industrially has surpassed an alarming limits which, if other alternative and environmental friendly materials are not made in practice, would be greatly detrimental to the environment, and the living beings as a result; because cement manufacturing contributes over $5 \%$ of global $\mathrm{CO}_{2}$ emissions which with more dependence would augment [4]. With the

* Corresponding author: shanker.lal@faculty.muet.edu.pk

\section{dol http://dx.doi.org/10.28991/cej-03091166}

$>$ This is an open access article under the CC-BY license (https://creativecommons.org/licenses/by/4.0/).

(C) Authors retain all copyrights. 
increasing growth in population and the rising demand of concrete in infrastructure, the natural sources of cement production are being eroded and henceforth, its alternatives are the need of time to save the natural resources for the next generations to come. Besides the environmental hazardous of cement manufacturing, agricultural as well as industrial wastes have acutely stimulated the waste and pollution troubles. The various alternative waste disposal materials and by-products like fly ash, rice husk ash, bottom ash, sugar bagasse ash, crumb rubber, brick aggregates etc. are the only viable and available sources to substitute, and their apt and suitable use would ward away the eco-system deterioration altogether with preservability of sources of cement production. As this waste is available in great abundance with no commercial value and very meagre cost of transportation. Their use can enhances practical and economic benefits in construction industry and can be an easy way forward to waste management. Apart from other alternatives which utilize waste, thus conserving natural resources and safeguarding the essence of life- environment, the rice husk ash is widely used as cement replacement in concrete because it has pozzolanic properties which enhance the strength of concrete [1]. This research focuses on the use of rice husk ash (waste stuff) in concrete to replace cement partially.

Around 600 million tons of rice paddy are being produced each year throughout the world which generate about 120 million tons of rice husk. Every ton of rice paddy produces about 0.20 tons of husk and on combustion of every ton of husk produces about 0.18 to 0.20 tons of ash $[4,5]$. According to the research which was conducted in Niger State reveals that rice grains were generated about 96,660 tons in year 2000 [6]. Utilization of rice is around 500.5 million tons in the world currently, estimated in 2014/15 [7, 8]. Most of the husk, produced from the processing of sifting rice, is either burnt or dumped as a waste. But for preparation of RHA, it follows three step process; collection of rice husk, controlled or uncontrolled burning of husk and then grinding of burnt husk as shown in Figure 1. According to the study of Houston, D. F. (1972); RHA produced by burning rice husk at $600-700{ }^{\circ} \mathrm{C}$ temperatures for 2 hours contains $90-95 \%$ of $\mathrm{SiO}_{2}, 1-3 \%$ of $\mathrm{K}_{2} \mathrm{O}$ and $<5 \%$ unburned carbon [9].

RHA is used in the production of high-performance and high-durable concrete which has been presented in various research papers [10-11]. The report present in 2009, shows that the maximum compressive strength was obtained by using 10\% RHA as replacement of cement and when this amount of RHA surpassed 10\% then compressive strength decreased significantly [12]. In the manufacturing of cheap concrete, RHA is used as a silica fume (cement) replacement materials as well as an admixture [13]. The chemical analysis report as conducted by [14] shows that RHA is chemically same as OPC.

Ologunagba et al. conducted the research work on mechanical properties of concrete by using RHA at various percentages of $0 \%-20 \%$ by the weight of cement. In this experimental work, the concrete cubes were made of 1:2:4 concrete mix ratio at water-cement ratio of 0.44 and cured at 7, 14, 21 and 28 days. It was observed that the compressive strength measured $24 \mathrm{~N} / \mathrm{mm}^{2}$ at 28 days by using $10 \%$ RHA in concrete as a partial replacement of cement [15].

The study which was conducted by Mehta, P.K. (1992) depicts that RHA is a highly porous and lightweight materials and also, it contains a very high external surface area about $50-1000 \mathrm{~m}^{2} / \mathrm{g}$. RHA contains highly cellular form which is used with cement that enhance stability and workability, and reduce the heat evolution and plastic shrinkage [9]. RHA is an excellent insulator and it possess an active pozzolana which has several applications in the cement and concrete industry. RHA is obtained by open field burning method which is used for improving workability, strength and durability of concrete [16]. The silica present in the ash which undergoes structural transformations when temperature changes during combustion. Amorphous silica formed between $550{ }^{\circ} \mathrm{C}-800{ }^{\circ} \mathrm{C}$ and crystalline silica formed at more than $800^{\circ} \mathrm{C}$ temperatures [17-18]. RHA is also an agricultural waste which is produced 20-30\% of rice annually that found in mostly rice producing countries [19]. This waste is disposed-off material, which is found to become a natural pozzolana. Pozzolans are the materials containing reactive silica and/or Aluminum [20]. RHA, when mixed with lime in powdered form in the presence of water, it sets and hardens like cement [21]. The RHA is considered as waste product and has no useful application in most of the regions, so it is usually dumped in the open fields which cause environmental pollution. Mostly, now a days, the efforts are being made to reduce the environmental pollution by using suitable by products as supplementary cementing material [22]. Thus, the rice husk ash is rich in cementitious mineral that can be used in concrete manufacturing.

Ashwini et al. presented the report on the compressive strength of concrete by using RHA at various percentages of $0 \%-40 \%$ by the weight of cement. In this research work, the concrete specimens were prepared and cured at 3, 7 and 28 days. It was concluded that the compressive strength of concrete was increased $12 \%$ at 28 days by using $20 \%$ RHA in concrete as a partial replacement of cement [23].

Akhter conducted the experimental study on characterstatics strength of concrete blended with RHA of various percentages of $0 \%-20 \%$ by weight of cement. In this research work, the concrete specimens were made and cured at 7 and 28 days. It was noted that the compressive strength of concrete was increased $15.74 \%$ at 28 days by using $10 \%$ RHA in concrete as a partial replacement of cement [24]. 
The source of rice husk ash determine important role in the variation characteristics of cementitious material [25]. The report was presented in 2004, shows that particle size of RHA is finer than OPC, which improves the properties of concrete [26]. The quality and strength desired in concrete is fundamentally related to its compressive strength [27]. This study is carried out by using of RHA in concrete, it was further established that the size of RHA is 25 micron and it plays important role as a filler in cement. RHA used in concrete as a partially replacement of OPC can decrease the emission of greenhouse gasses to a great extent and also reduce the environmental pollution [28]. Further, the emission of $\mathrm{CO}_{2}$ into the atmosphere produces environmental pollution during the process of clinker or limestone. For this reason, other supplementary cementing materials are used at the place of limestone-based clinker to minimize the use of Portland cement [29]. The RHA, therefore, can be used as a construction material to solve the problem of waste management which improves the environmental protection, sustainability and the economic value of rice husk ash [30]. Moreover, rice husk is a supplementary material which can be used as fine aggregate in mixing mortar [31].

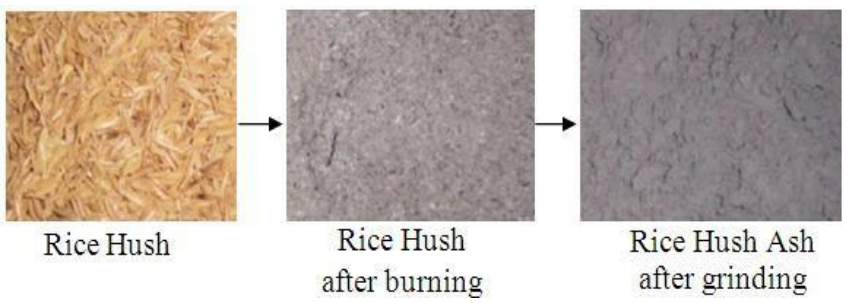

Figure 1. Steps for obtaining RHA

Overall, the aim of this research is to investigate the effect of RHA on mechanical properties of concrete at different water-cement ratios and:

- To know the effect of $10 \%$ partial replacement of RHA with cement on compressive and splitting tensile strength of concrete.

- To analysis and establish the correlation between RHA and strength (compressive and splitting tensile) at various water-cement ratios.

\section{Materials and Methods}

In this research work, methodology adopted to check the physical properties (workability, compressive and splitting tensile strength) of concrete at partial replacement of cement with RHA. For this reason, two types of concrete standard specimens (cubes, 4" $\times 4 " \times 4$ " and cylinders, 4" diameter and 8" height) were cast in structural concrete and laboratory of QUCEST Larkana. Total 144 concrete cylinders and 72 cubes were cast at 1:2:4 mix ratio with various w/c ratios i.e $0.45,0.50$ and 0.60 . Further, at each w/c ratio total 24 cubes and 48 cylinders were cast as given in Table 1. Both types of specimens are cured at 7, 14, 28 and 56 days curing period. Three specimens at each W/C ratio and curing age are cast and tested for compressive and splitting tensile strength of concrete in Universal Testing Machine (UTM). Finally, the average of all three specimens at specific w/c ratio is taken as ultimate result of particular test.

Table 1. Quantity of specimen

\begin{tabular}{|c|c|c|c|c|}
\hline Specimens & Curing Ages & Water-cement ratio & Plain Concrete & $10 \%$ RHA \\
\hline \multirow{4}{*}{$\begin{array}{l}\text { Cylinders for Cylindrical } \\
\text { compressive strength }\end{array}$} & 7 days & & $3+3+3$ & $3+3+3$ \\
\hline & 14 days & $0.45+0.50+0.60$ & $3+3+3$ & $3+3+3$ \\
\hline & 28 days & & $3+3+3$ & $3+3+3$ \\
\hline & 56 days & & $3+3+3$ & $3+3+3$ \\
\hline Total & & & 36 & 36 \\
\hline \multirow{4}{*}{$\begin{array}{l}\text { Cylinders for Splitting } \\
\text { tensile strength }\end{array}$} & 7 days & & $3+3+3$ & $3+3+3$ \\
\hline & 14 days & & $3+3+3$ & $3+3+3$ \\
\hline & 28 days & $0.45+0.50+0.60$ & $3+3+3$ & $3+3+3$ \\
\hline & 56 days & & $3+3+3$ & $3+3+3$ \\
\hline Total & & & 36 & 36 \\
\hline \multirow{4}{*}{$\begin{array}{l}\text { Cubes for Cubical } \\
\text { Compressive strength }\end{array}$} & 7 days & & $3+3+3$ & $3+3+3$ \\
\hline & 14 days & $0.45+0.50+0.60$ & $3+3+3$ & $3+3+3$ \\
\hline & 28 days & & $3+3+3$ & $3+3+3$ \\
\hline & 56 days & & $3+3+3$ & $3+3+3$ \\
\hline Total & & & 36 & 36 \\
\hline
\end{tabular}


Locally available materials in the vicinity of Larkana city are used in this research. Ordinary Portland cement (OPC) with brand name Lucky cement is used. While fine (natural hill sand) and coarse (artificially crushed) aggregate are used after necessary preliminary tests which are tabulated in table 2 . Husk of rice is obtained from waste dumps of husk in rice fields nearby areas. This husk was freely available and considered as waste or by-product of rice by the rice paddy formers. Further, collected husk is then burnt in closed combustion chamber at around $600-850{ }^{\circ} \mathrm{C}$ temperature to produce rice husk ash. Produced ash is left for 24 hours for cooling and then collected husk is sieved through \#30 sieve for removing any unwanted materials. Moreover, processed RHA is batched by weight and used as cement replacement in concrete.

Table 2. Properties of fine and coarse aggregates

\begin{tabular}{cccc}
\hline Sr. No. & Properties & Fine Aggregates & Coarse Aggregates \\
\hline 01 & Fineness Modulus & 2.11 & -- \\
02 & Specific Gravity & 2.65 & 2.63 \\
03 & Water absorption & $1.8 \%$ & $1.4 \%$ \\
04 & Bulk density (compacted) & $118.78 \mathrm{lb} / \mathrm{ft}^{3}$ & $98.77 \mathrm{lb} / \mathrm{ft}^{3}$ \\
\hline
\end{tabular}

\section{Results and Discussion}

\subsection{Workability Test}

Slump cone testing method based on ASTM C 143 is followed for assessing the workability of fresh concrete. The experimental results show that the workability of concrete blended with $10 \%$ RHA at $0.45,0.50$ and $0.60 \mathrm{w} / \mathrm{c}$ ratio is less than the workability of plain concrete with same w/c ratios as shown in Figure 2. Further, workability increases with increasing water cement ratio in both plain as well as blended concrete. Therefore, results of flow of concrete gets maximum at $0.60 \mathrm{w} / \mathrm{c}$ ratio which is $55 \%$ and $34 \%$ in plain and concrete with $10 \%$ RHA respectively as compared to $0.45 \mathrm{w} / \mathrm{c}$ ratio.

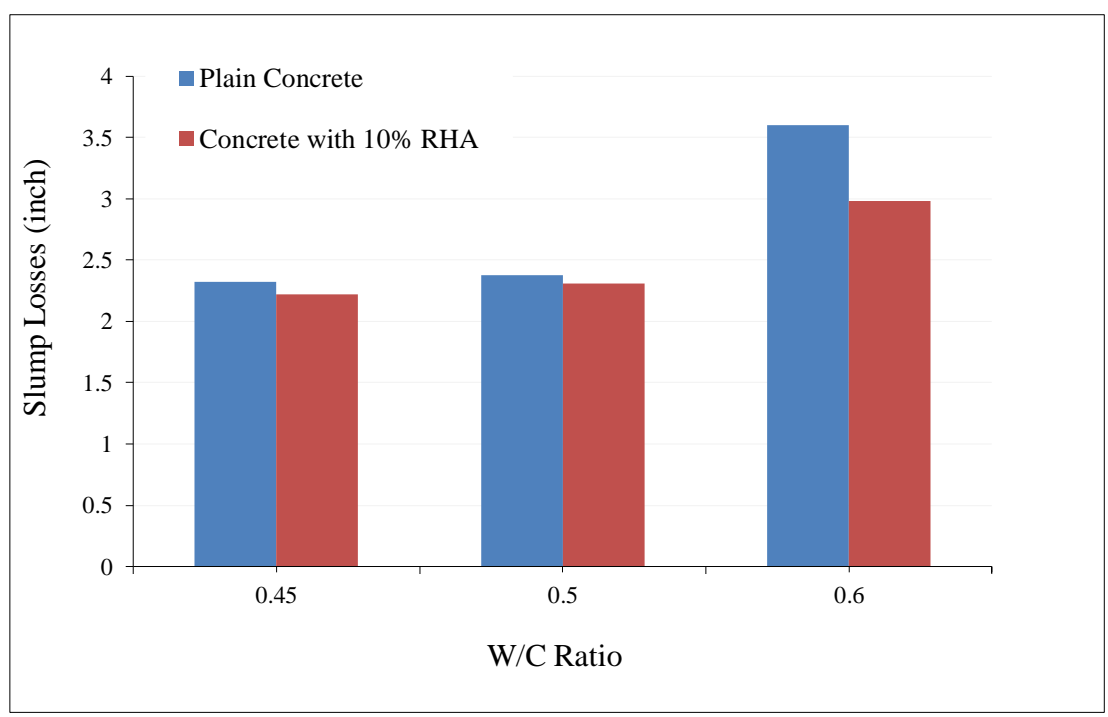

Figure 2. Slump loss values at 1:2:4 mix ratio with various $\mathrm{W} / \mathrm{C}$ ratio

\subsection{Compressive Strength}

The compressive strength conducted on Universal Testing Machine (UTM) by following the ASTM C39 standard testing procedure. Two types of specimens i.e. cube and cylinder were tested. For each w/c ratio and curing age three cubes and three cylinders were cast and tested. The average values of all specimens at particular w/c ratio and curing age are shown in Table 3, 4, 5, 6, 7 and 8, Figure 3,4,5,6, 7 and 8. In all graphs, plain concrete specimens are compared with concrete blended with $10 \%$ RHA with various w/c ratios. The experimental reports show that the compressive strength of plain and blended concrete gets increase with curing ages i.e. maximum of $36.4 \mathrm{MPa}$ and $41.68 \mathrm{MPa}$ at 56 days and minimum of $23.6 \mathrm{MPa}$ and $24.54 \mathrm{MPa}$ at 7 days respectively, at $0.45 \mathrm{w} / \mathrm{c}$ ratio. Generally, as water content in concrete is increased the strength tends to decrease but with enhanced curing age it increases in plain as well as concrete with $10 \%$ RHA. Maximum compressive strength is recorded at $0.45 \mathrm{w} / \mathrm{c}$ ratio and 56 days curing period and minimum at $0.60 \mathrm{w} / \mathrm{c}$ ratio and 7 days curing age. It is, further, observed that the cubical compressive strength gets maximum at $14.51 \%$ and cylindrical compressive strength increase at $12 \%$ at $0.45 \mathrm{w} / \mathrm{c}$ ratio as compare to normal concrete. 
Table 3. Cubical Compressive Strength of mix ratio 1:2:4 at $0.45 \mathrm{~W} / \mathrm{C}$ ratio

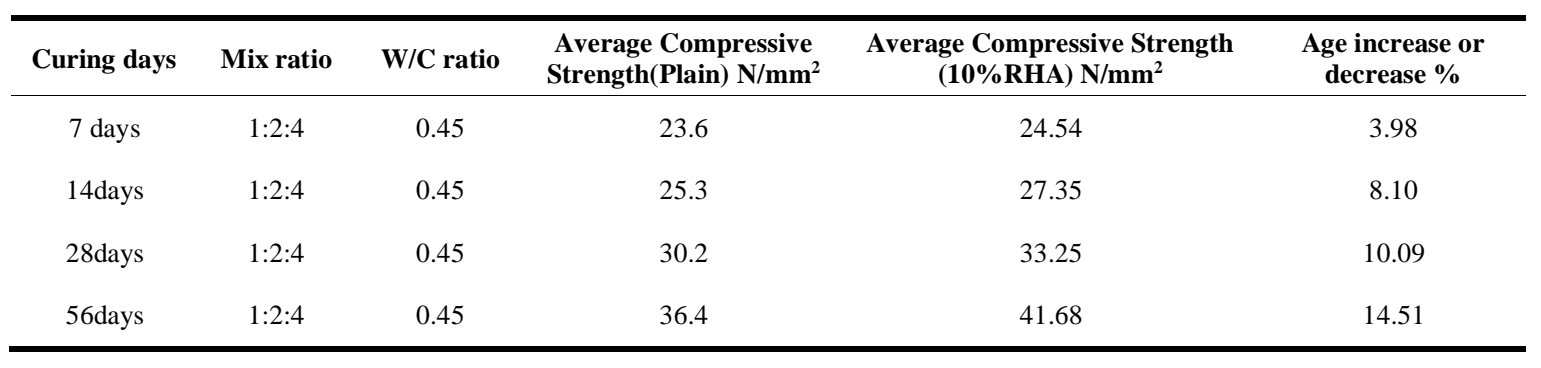

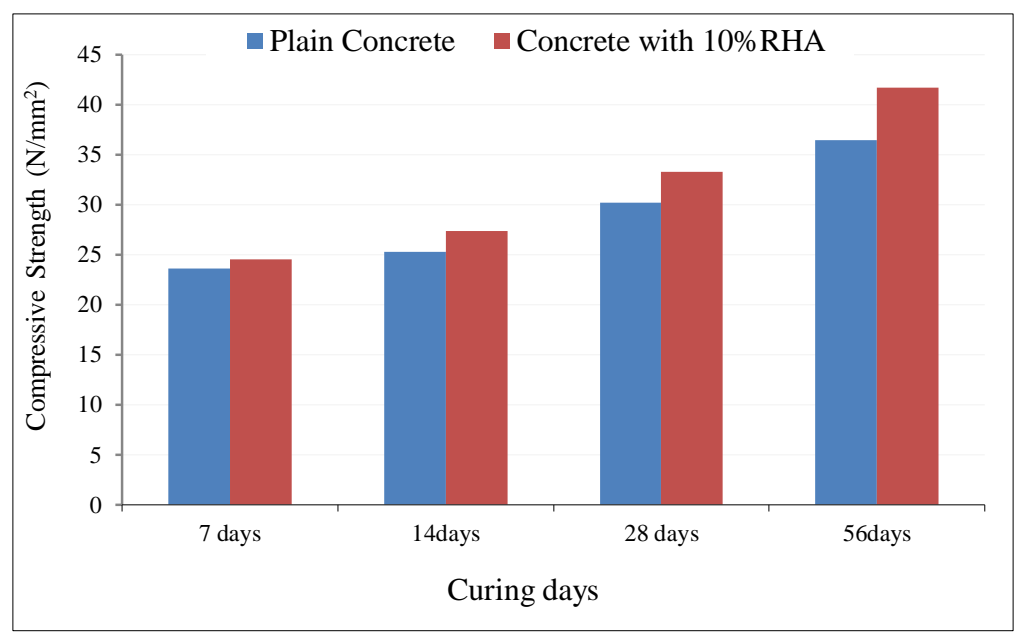

Figure 3. Cubical compressive strength of concrete at 1:2:4 mix ratio with $0.45 \mathrm{~W} / \mathrm{C}$ ratio

Table 4. Cubical Compressive Strength of mix ratio 1:2:4 at $0.50 \mathrm{~W} / \mathrm{C}$ ratio

\begin{tabular}{|c|c|c|c|c|c|}
\hline Curing days & Mix ratio & w/c ratio & $\begin{array}{l}\text { Average Compressive } \\
\text { Strength(Plain) N/mm² }\end{array}$ & $\begin{array}{c}\text { Average Compressive } \\
\text { Strength }(10 \% \text { RHA }) \text { N/mm }\end{array}$ & $\begin{array}{c}\text { Age increase or } \\
\text { decrease } \%\end{array}$ \\
\hline 7 days & $1: 2: 4$ & 0.50 & 20.3 & 21 & 3.45 \\
\hline 14days & $1: 2: 4$ & 0.50 & 23.7 & 25.5 & 7.59 \\
\hline 28 days & $1: 2: 4$ & 0.50 & 27.58 & 30.2 & 9.49 \\
\hline
\end{tabular}

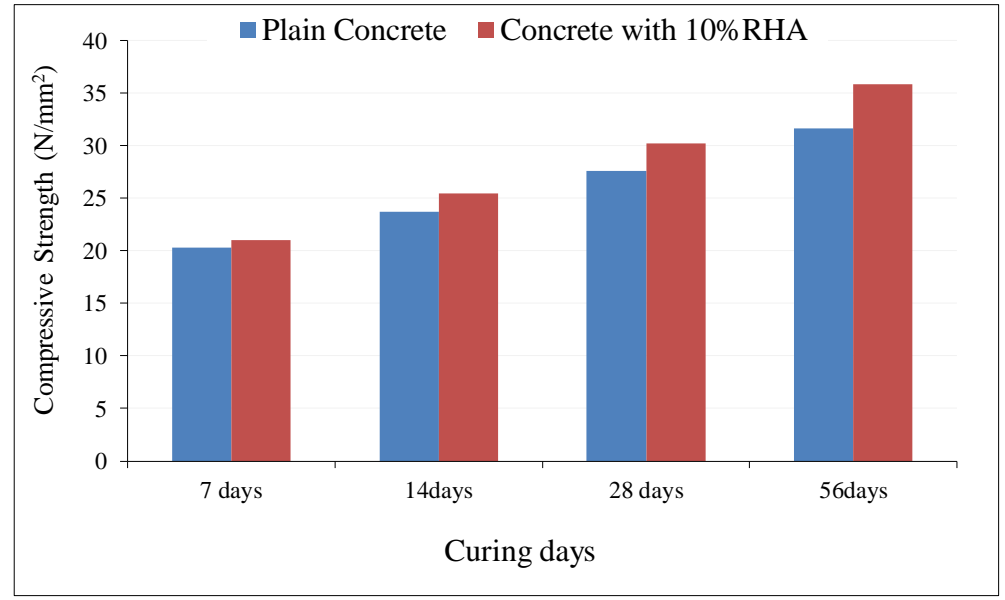

Figure 4. Cubical compressive strength of concrete at $1: 2: 4 \mathrm{mix}$ ratio with $0.50 \mathrm{~W} / \mathrm{C}$ ratio 
Table 5. Cubical Compressive Strength of mix ratio 1:2:4 at $0.60 \mathrm{~W} / \mathrm{C}$ ratio

\begin{tabular}{|c|c|c|c|c|c|}
\hline Curing days & Mix ratio & w/c ratio & $\begin{array}{l}\text { Average Compressive } \\
\text { Strength(Plain) N/mm } \\
\end{array}$ & $\begin{array}{c}\text { Average Compressive } \\
\text { Strength }(10 \% \text { RHA) N/mm }\end{array}$ & $\begin{array}{c}\text { Age increase or } \\
\text { decrease } \%\end{array}$ \\
\hline 7 days & $1: 2: 4$ & 0.60 & 19.8 & 20.4 & 3.03 \\
\hline 14days & $1: 2: 4$ & 0.60 & 22.4 & 23.86 & 6.52 \\
\hline 28 days & $1: 2: 4$ & 0.60 & 26.8 & 29.10 & 8.58 \\
\hline 56days & $1: 2: 4$ & 0.60 & 29.9 & 33.5 & 12.04 \\
\hline
\end{tabular}

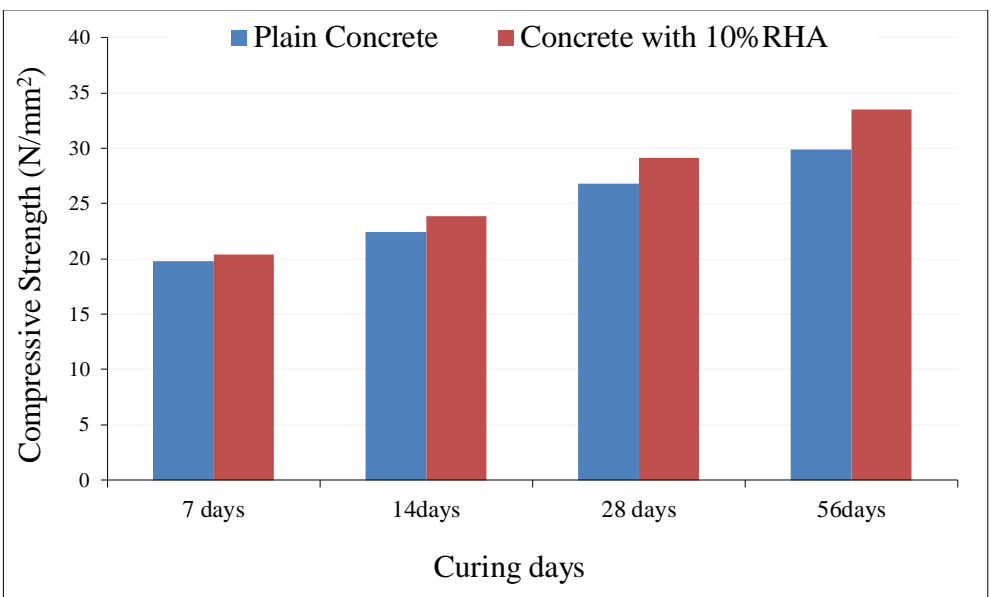

Figure 5. Cubical compressive strength of concrete at 1:2:4 mix ratio with $0.60 \mathrm{~W} / \mathrm{C}$ ratio

Table 6. Cylindrical Compressive Strength at 1:2:4 mix ratio with $0.45 \mathrm{~W} / \mathrm{C}$ ratio

\begin{tabular}{cccccc}
\hline Curing days & Mix ratio & w/c ratio & $\begin{array}{c}\text { Average Compressive } \\
\text { Strength(Plain) N/mm }\end{array}$ & $\begin{array}{c}\text { Average Compressive } \\
\text { Strength(10\% RHA) N/mm }\end{array}$ & $\begin{array}{c}\text { Age increase or } \\
\text { decrease } \%^{2}\end{array}$ \\
\hline 7 days & $1: 2: 4$ & 0.45 & 16.4 & 16.89 & 2.98 \\
14days & $1: 2: 4$ & 0.45 & 20.64 & 22.085 & 7.00 \\
28 days & $1: 2: 4$ & 0.45 & 25.9 & 28.23 & 8.99 \\
56days & $1: 2: 4$ & 0.45 & 30.5 & 34.16 & 12 \\
\hline
\end{tabular}

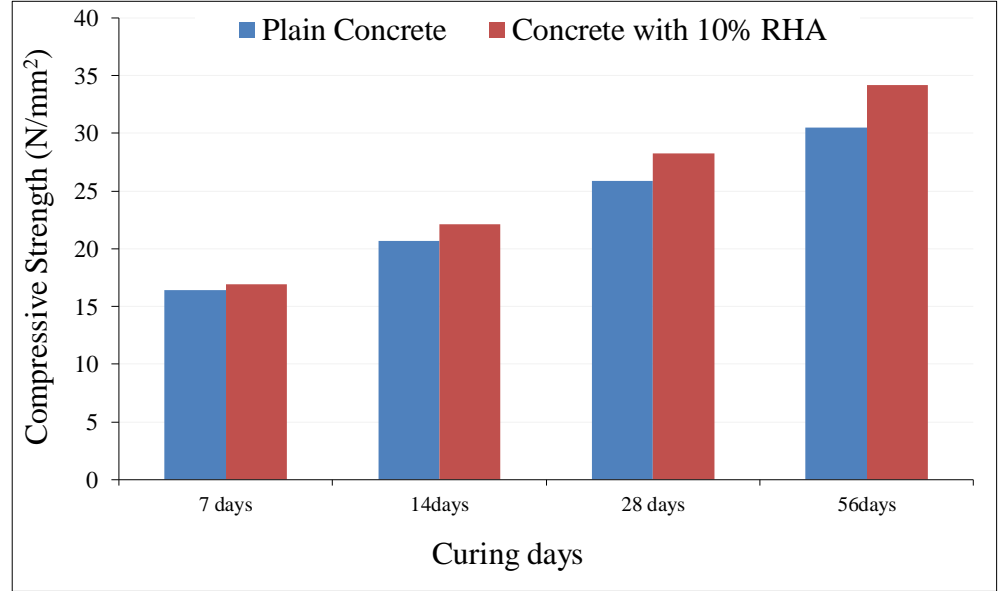

Figure 6. Cylindrical compressive strength of concrete at $1: 2: 4$ mix ratio with $0.45 \mathrm{~W} / \mathrm{C}$ ratio

Table 7. Cylindrical Compressive Strength at 1:2:4 mix ratio with $0.50 \mathrm{~W} / \mathrm{C}$ ratio

\begin{tabular}{|c|c|c|c|c|c|}
\hline Curing days & Mix ratio & w/c ratio & $\begin{array}{l}\text { Average Compressive } \\
\text { Strength(Plain) N/mm² }\end{array}$ & $\begin{array}{c}\text { Average Compressive } \\
\text { Strength(10\% RHA) N/mm }\end{array}$ & $\begin{array}{c}\text { Age increase or } \\
\text { decrease } \%\end{array}$ \\
\hline 7 days & $1: 2: 4$ & 0.50 & 14.27 & 14.69 & 2.94 \\
\hline 28 days & $1: 2: 4$ & 0.50 & 20.67 & 22.44 & 8.56 \\
\hline 56days & $1: 2: 4$ & 0.50 & 23.92 & 26.68 & 11.54 \\
\hline
\end{tabular}




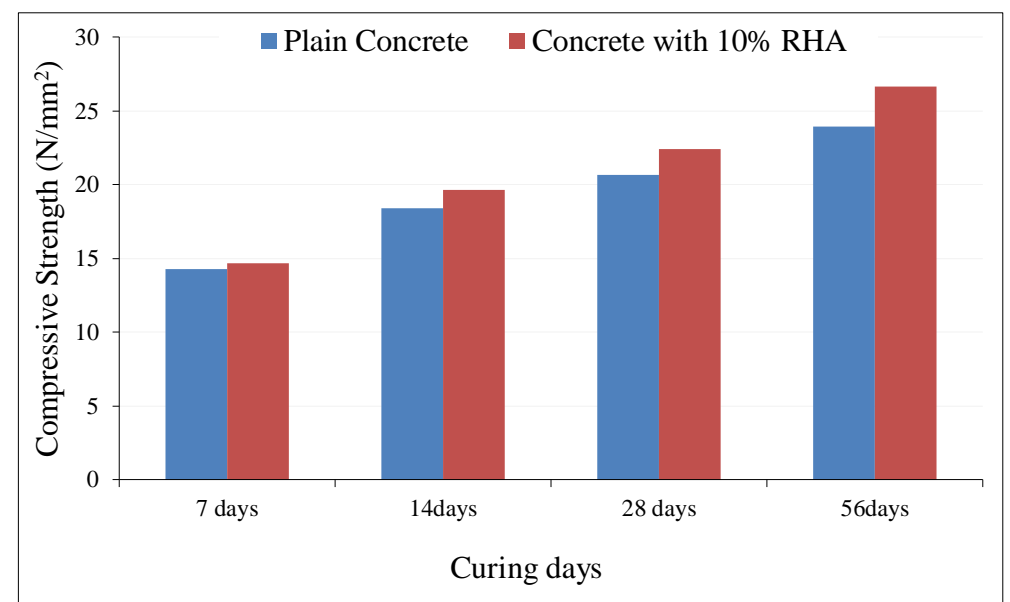

Figure 7. Cylindrical compressive strength of concrete at 1:2:4 mix ratio with $0.50 \mathrm{~W} / \mathrm{C}$ ratio

Table 8. Cylindrical Compressive Strength at 1:2:4 mix ratio with 0.60 W/C ratio

\begin{tabular}{cccccc}
\hline Curing days & Mix ratio & w/c ratio & $\begin{array}{c}\text { Average Compressive } \\
\text { Strength(Plain)N/mm }\end{array}$ & $\begin{array}{c}\text { Average Compressive } \\
\text { Strength(10\% RHA) N/mm }\end{array}$ & $\begin{array}{c}\text { \% age increase or } \\
\text { decrease }^{2}\end{array}$ \\
\hline 7 days & $1: 2: 4$ & 0.60 & 13.64 & 13.95 & 2.27 \\
14days & $1: 2: 4$ & 0.60 & 15.78 & 16.81 & 6.53 \\
28 days & $1: 2: 4$ & 0.60 & 18.2 & 19.53 & 7.31 \\
56days & $1: 2: 4$ & 0.60 & 20.83 & 23.04 & 10.61 \\
\hline
\end{tabular}

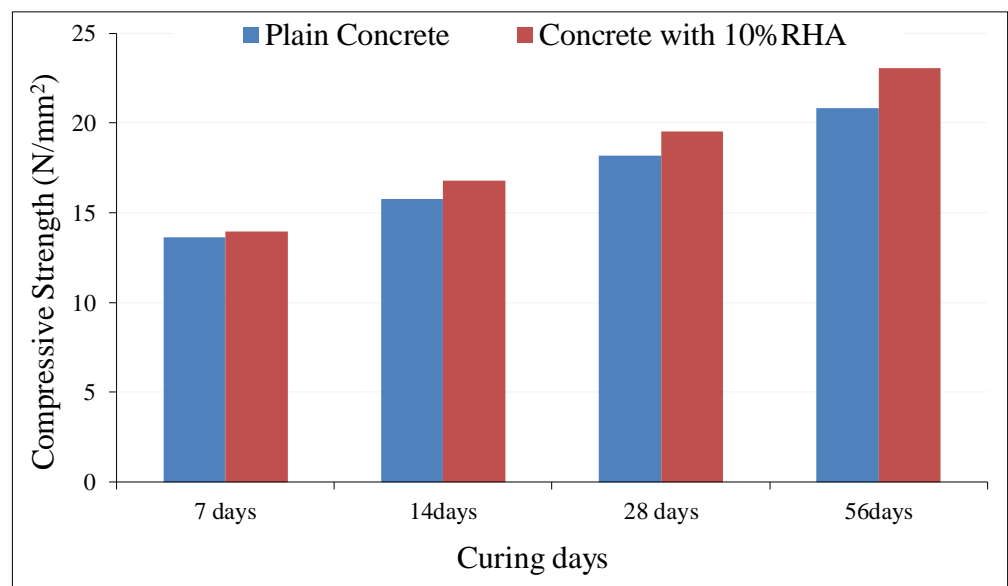

Figure 8. Cylindrical compressive strength of concrete at 1:2:4 mix ratio with $0.60 \mathrm{~W} / \mathrm{C}$ ratio

\subsection{Splitting Tensile Strength of Concrete}

Splitting tensile strength testing procedure of ASTM C496 is followed for evaluating the tensile behaviour of concrete. In this research, total 72 cylinders of plain and concrete with 10\% RHA were caste and tested in UTM. Similarly that of compressive strength, this test is also evaluated at $0.45,0.50$ and $0.60 \mathrm{w} / \mathrm{c}$ ratios and 7, 14, 28 and 56 days curing period. Overall, experimental results show that the splitting tensile strength of plain and blended concrete gets maximum of 4.65 MPa and 4.2 MPa respectively at $0.45 \mathrm{w} / \mathrm{c}$ ratio and 56 days curing age.

Moreover, splitting tensile strength decreased gradually with increasing w/c ratio; maximum at 0.45 and minimum at 0.60 as shown in Figure 9, 10, 11 and Table 9, 10, 11. This value of concrete with 10\% RHA is 10.71\% greater than plain concrete at $0.45 \mathrm{w} / \mathrm{c}$ ratio and curing age of 56 days. Lower early strength may be due evaporation of less heat of hydration due to presence of calcium silicate and this at latter stage caused gain in strength with prolonged curing age.

Table 9. Tensile Strength at 1:2:4 mix ratio with $0.45 \mathrm{~W} / \mathrm{C}$ ratio

\begin{tabular}{cccccc}
\hline Curing days & Mix ratio & w/c ratio & $\begin{array}{c}\text { Average Tensile } \\
\text { Strength(Plain)N/mm }\end{array}$ & $\begin{array}{c}\text { Average Tensile } \\
\text { Strength(10\% RHA) N/mm }\end{array}$ & $\begin{array}{c}\text { \% age increase or } \\
\text { decrease }\end{array}$ \\
\hline 7 days & $1: 2: 4$ & 0.45 & 2.8 & 2.91 & 3.93 \\
14days & $1: 2: 4$ & 0.45 & 3.21 & 3.4 & 5.91 \\
28 days & $1: 2: 4$ & 0.45 & 3.64 & 3.96 & 8.79 \\
56days & $1: 2: 4$ & 0.45 & 4.20 & 4.65 & 10.71 \\
\hline
\end{tabular}




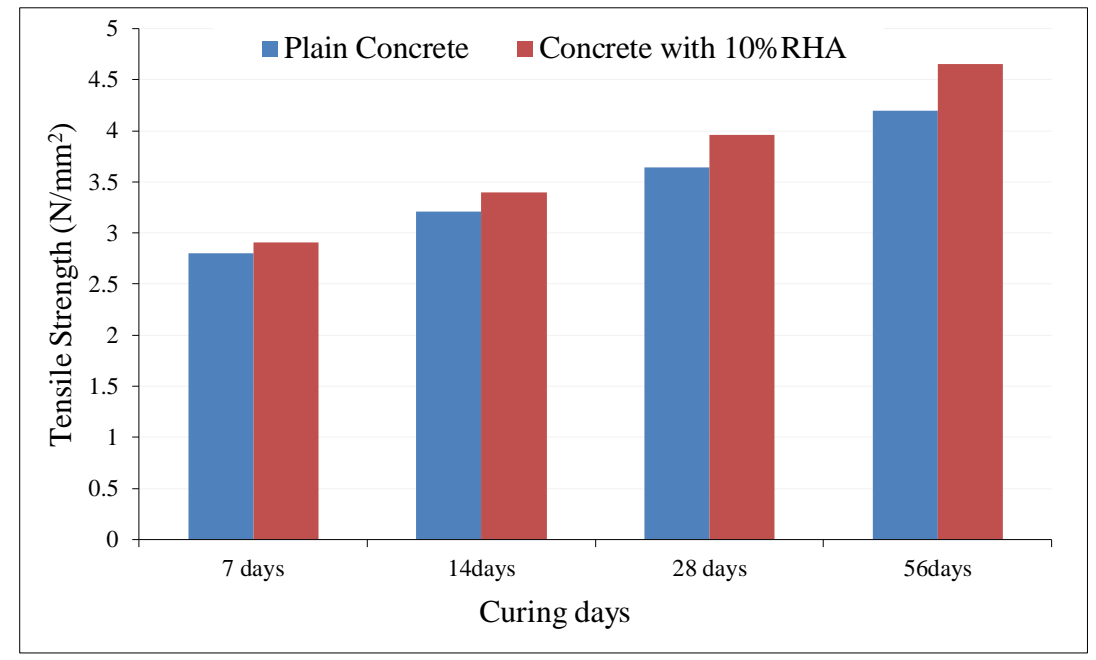

Figure 9. Splitting Tensile strength of concrete at $1: 2: 4$ mix ratio with $0.45 \mathrm{~W} / \mathrm{C}$ ratio

Table 10. Tensile Strength at 1:2:4 mix ratio with $0.50 \mathrm{~W} / \mathrm{C}$ ratio

\begin{tabular}{cccccc}
\hline Curing days & Mix ratio & w/c ratio & $\begin{array}{c}\text { Average Tensile } \\
\text { Strength(Plain)N/mm }\end{array}$ & $\begin{array}{c}\text { Average Tensile } \\
\text { Strength(10\% RHA) N/mm } \mathbf{m}^{2}\end{array}$ & $\begin{array}{c}\text { \% age increase or } \\
\text { decrease }^{2}\end{array}$ \\
\hline 7 days & $1: 2: 4$ & 0.50 & 2.2 & 2.28 & 3.64 \\
14days & $1: 2: 4$ & 0.50 & 2.63 & 3.78 & 8.70 \\
28 days & $1: 2: 4$ & 0.50 & 3.16 & 4.26 & 10.36 \\
56days & $1: 2: 4$ & 0.50 & 3.86 & & 3.23 \\
\hline
\end{tabular}

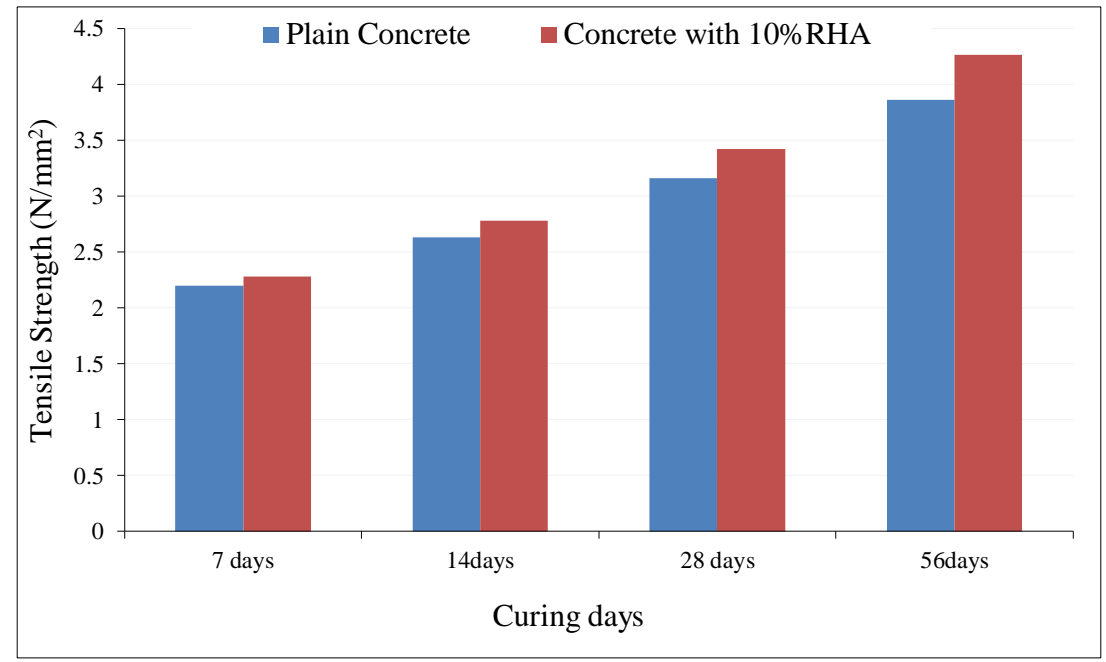

Figure 10. Splitting Tensile strength of concrete at 1:2:4 mix ratio with $0.50 \mathrm{~W} / \mathrm{C}$ ratio

Table 11. Tensile Strength at 1:2:4 mix ratio with $0.60 \mathrm{~W} / \mathrm{C}$ ratio

\begin{tabular}{cccccc}
\hline Curing days & Mix ratio & w/c ratio & $\begin{array}{c}\text { Average Tensile } \\
\text { Strength(Plain) N/mm }\end{array}$ & $\begin{array}{c}\text { Average Tensile } \\
\text { Strength(10\% RHA) N/mm }\end{array}$ & $\begin{array}{c}\text { \% age increase or } \\
\text { decrease }\end{array}$ \\
\hline 7 days & $1: 2: 4$ & 0.60 & 1.59 & 1.64 & 3.15 \\
14days & $1: 2: 4$ & 0.60 & 1.95 & 2.05 & 5.13 \\
28 days & $1: 2: 4$ & 0.60 & 2.8 & 3.024 & 8.00 \\
56days & $1: 2: 4$ & 0.60 & 3.2 & 3.52 & 10.00 \\
\hline
\end{tabular}




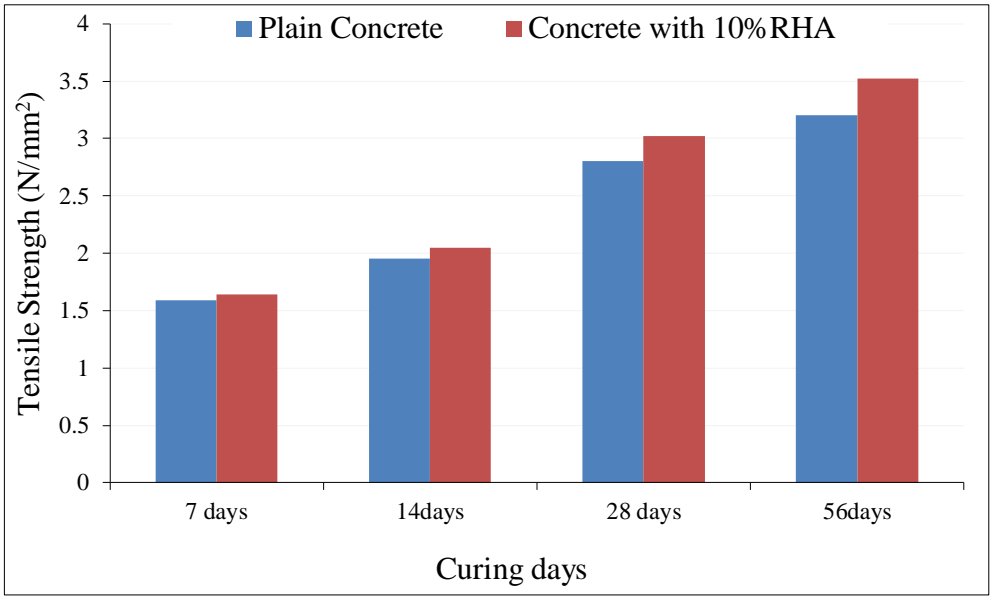

Figure 11. Splitting Tensile strength of concrete at $1: 2: 4 \mathrm{mix}$ ratio with $0.45 \mathrm{~W} / \mathrm{C}$ ratio

\section{Conclusions}

This study conducted on mechanical properties of concrete by utilizing the RHA as partial replacement of cement; concludes that:

- The cubical compressive strength of concrete with $10 \%$ RHA gets increased to14.51\% as compared to normal concrete at 56 days curing time with $0.45 \mathrm{w} / \mathrm{c}$ ratio.

- The cylindrical compressive strength of concrete with $10 \%$ RHA gets increased to $12 \%$ as compared to normal concrete at 56 days curing time with $0.45 \mathrm{w} / \mathrm{c}$ ratio.

- The splitting tensile strength of concrete with $10 \%$ RHA gets increased to $10.71 \%$ as compared to normal concrete at 56 days curing time with $0.45 \mathrm{w} / \mathrm{c}$ ratio.

- Concrete with 10\% RHA can gives better results at longer curing time and can economically be used in construction industry.

- Various other researches are possible by adding admixtures for high workability and strength with different proportions of RHA.

\section{References}

[1] Sourav Ghosal and S.C.Moulik. "Use of Rice Husk Ash as Partial Replacement with Cement In Concrete- A Review". International journal of engineering research, Volume No.4, Issue No.9 (2015): 506-509. doi: 10.5958/2319-6890.

[2] Nguyen, Hoang, Valter Carvelli, Elijah Adesanya, Paivo Kinnunen, and Mirja Illikainen. "High Performance Cementitious Composite from Alkali-Activated Ladle Slag Reinforced with Polypropylene Fibers." Cement and Concrete Composites 90 (July 2018): 150-160. doi:10.1016/j.cemconcomp.2018.03.024.

[3] Meghwar S.L., Kheskheli G.B., Kumar Aneel, Mahar R.B., "Recycling of Human Scalp Hair as Environmental Friendly Material in Cement Concrete"; In: Harijan, K. ed., Proceedings of the 4th International Conference on Energy, Environment and Sustainable Development, Mehran UET Jamshoro, Sindh, Pakistan: Energy and Environment Engineering Research Group, November 01-03, 2016, Paper ID: EESD_2016_54.

[4] Krishna NK, Sandeep S, Mini KM. "Study on concrete with partial replacement of cement by rice husk ash". IOP Conf Ser Mater Sci Eng. 2016; 149(1). doi: 10.1088/1757-899X/149/1/012109.

[5] Nakoo Y., "Rice: Post Harvest Technology”, ACE Corporation, Tokyo, p. 431, 1999.

[6] Edodzigi M., “Cropped-Area and Yield Survey (CAYS)”, Report 2000 Wet Season, Agric.Development Project (A.D.P), Niger State, Nigeria p. 2, 2001.

[7] Nations, F.a.A.O.o.t.U., "World paddy production". 2014.

[8] Zareei, Seyed Alireza, Farshad Ameri, Farzan Dorostkar, and Mojtaba Ahmadi. "Rice Husk Ash as a Partial Replacement of Cement in High Strength Concrete Containing Micro Silica: Evaluating Durability and Mechanical Properties." Case Studies in Construction Materials 7 (December 2017): 73-81. doi:10.1016/j.cscm.2017.05.001.

[9] H. Premalal, H. Ismail and A. Baharin. "Comparison of the Mechanical Properties of Rice Husk powder filled Polypropylene Composites with Talc filled Polypropylene Composites”. Polymer Testing, vol. 21, no. 7, (2002): 833-839. PII: S01 42 9418(02)00018-1.

[10] V. M. Srivastava, I. O. Mall and I. M. Mishra. "Characterization of Mesoporous Rice Husk Ash (RHA) and Adsorption Kinetics of Metal Ions from Aqueous Solution onto RHA". Journal of Hazardous Materials, vol. 134, no. 1, (2006): 257-267. 
doi: 10.1016/j.jhazmat.2005.11.052.

[11] A. H. Mahvi, A. Maleki and A. Eslami. "Potential of Rice Husk and Rice Husk Ash for Phenol Removal in Aqueous Systems". American Journal of Applied Science, vol. 1, no. 4, (2004): 321-326. doi: 10.3844/ajassp.2004.321.326.

[12] Dabai MU, Muhammad C, Bagudo BU, Musa A. "Studies on the Effect of Rice Husk Ash as Cement Admixture". Niger J Basic Appl Sci. 2009;17(2):252-256. doi:10.4314/njbas.v17i2.49917.

[13] G. A Habeeb, M. M Fayyaah. "Rice Husk Ash Concrete: the Effect of RHA Average Particle Size on Mechanical Properties and Drying Shrinkage”. Australian Journal of Basic Applied Sciences, Vol 3(3) (2009): 1616-1622. doi: 10.22587/ajbas.2017.11.13.2.

[14] N. Yalcin and V. Sevinc. "Studies on Silica obtained from Rice Husk". Ceramics International, vol. 27, no. 2, (2001): $219-224$. doi: 10.1016/S0272-8842(00)00068-7.

[15] I.B. Ologunagba1, A.S. Daramola, A.O. Aliu. "Feasibility of using Rice Husk Ash as Partial Replacement for Concrete". International journal of engineering Trends and technology, 30(5) (2015): 267-269. doi: 10.1016/j.tics.2006.07.005.

[16] Reddy, D. "Marine Durability Characteristics of Rice Husk Ash-Modified Reinforced Concrete Fourth LACCEI International Latin American and Caribbean Conference for Engineering and Technology (LACCET'2006) June 2006". Mayaguez, Puerto Rico.

[17] Zhang, M.H. and V.M. Malhotra. "High-performance concrete incorporating rice husk ash as a supplementary cementing material". Aci Materials Journal, 1996. 93(6): 629-636. doi: 10.14359/9870.

[18] Food and Agriculture Organization of the United Nations. "World paddy production. 2008". [Accessed 26 December 2008].

[19] Obam, S. O. "Compressive Strength of RHA Concrete”. Nigerian Journal of Technology, Vol. 25, No. 2 (2006): 1-10. doi: 10.4314/njt.v36i4.4.

[20] ASTM Standard C311. "Standard Test Methods for Sampling and testing Fly Ash or Natural Pozzolans for use in Portland cement concrete". West Conshohocken, Pennsylvania, 1994.

[21] Chandrasekhar, S., P.N. Pramada, and J. Majeed. "Effect of calcination temperature and heating rate on the optical properties and reactivity of rice husk ash". Journal of Materials Science, 41(23) (2006): 7926-7933. doi: 10.1007/s10853-006-0859-0.

[22] Chandrasekhar, S., Satyanarayana, K.G., Pramada, P.N. "Review processing, properties and applications of reactive silica from rice husk - an overview”. Journal of Materials Science (2003) 38: 3159-3168. doi: 10.1023/A:1025157114800.

[23] Ashwini B V, Supriya GK, Sathish DM, B AD. “An Experimental Study on Rice Husk Ash”. International journal of innovative research in science, engineering and technology, Volume 6, issue 5(2017):8747-8751. doi: 10.15680/IJIRSET.2017.0605241.

[24] Mehnaza Akhter. "Experimental Study on Effect of Rice Husk Ash on Strength of Concrete". Volume 04, Issue 7, (July- 2017): 2349-9745. doi: 10.21884/IJMTER.2017.4218.505GF.

[25] Malhotra, V. Mohan, and Povindar Kumar Mehta. Pozzolanic and cementitious materials. CRC Press, 2014. doi: $10.1201 / 9781482296761$

[26] Nevile, A.M and Brooks, J.J. “Concrete Technology”, Singapore: Longman Ltd., 1990.

[27] Padma Rao, P. A. Pradhan Kumar and B. Bhaskar Singh. "A Study on Use of Rice Husk Ash in Concrete”. International Journal of Education and Applied Research, Vol. 4, Issue SPL-2, 2014.

[28] Rukzon S, Chindaprasirt P, Mahachai R. "Effect of grinding on chemical and physical properties of rice husk ash". Int J Miner Metall Mater. 16(2) (2009):242-247. doi: 10.1016/S1674-4799(09)60041-8.

[29] Akeke, G.A, Ephraim, M.E, Akobo I.Z.S and Ukpata, J.O. "Structural Properties of RHA”. International Journal of Engineering and Applied Sciences, Vol.3 Number 3 (2012): 57-62.

[30] Yang HS, Kim HJ, Son J, Park HJ, Lee BJ, Hwang TS. "Rice-husk flour filled polypropylene composites; mechanical and morphological study". Compos Struct. 63(3-4) (2004):305-312. doi: 10.1016/S0263-8223(03)00179-X.

[31] V. M. Srivastava, I. O. Mall and I. M. Mishra. "Characterization of Mesoporous Rice Husk Ash (RHA) and Adsorption Kinetics of Metal Ions from Aqueous Solution onto RHA". Journal of Hazardous Materials, vol. 134, no. 1, (2006): 257-267. doi: 10.1016/j.jhazmat.2005.11.052. 